\title{
The Protection of Women Refugees based on the Perspective of ASEAN Law: The Case of Rohingya Women Refugees*
}

\author{
Intan Soeparna* \\ DOI: https://doi.org/10.22304/pjih.v5n2.a2
}

Submitted: May 12, 2018 | Accepted: August 31, 2018

\begin{abstract}
The conflict of Rohingya has triggered human rights issues, including the ones that involve women refugees. Female Rohingya Refugees are facing the risks of sexual violence, abduction, trafficking, and prostitution. This situation indicates an urgent call for the realization of refugee protection, including the protection of women refugees according to ASEAN Law. ASEAN has made important institutional statements concerning the protection of women's human rights and the prevention of the violence against woman in its Human Right Law Regime. ASEAN also has made a statement to the Security Council on Women, Peace, and Security to address sexual violence in the conflicts that requires the tackling on the root-cause of the humanitarian disaster faced by Rohingya women refugees. However, the refugee's policies of some ASEAN members, such as Malaysia, Indonesia, and Thailand, indicate less commitment to protect refugees. The fact gives impacts to women refugees. This article attempts to analyze the ASEAN role to protect Rohingya women refugees based on ASEAN legal commitment, including the ASEAN Regime of Human Rights. The purpose of the study is to imply the ASEAN legal commitment on the protection of women's right and to improve protection for women refugees, especially the Rohingya refugees.
\end{abstract}

Keywords: ASEAN Human Rights Law, protection of women refugees, Rohingya refugees.

\begin{abstract}
Abstrak
Konflik Rohingya menimbulkan berbagai bentuk masalah hak asasi manusia, terutama untuk pengungsi perempuan. Perempuan beresiko terhadap kekesaran seksual, perdagangan manusia dan prostitusi. Situasi ini menunjukan pentingnya merealisasikan perlindungan pengungsi termasuk pengungsi perempuan berdasarkan Hukum ASEAN, karena ASEAN sendiri telah membuat pernyataan penting berkaitan dengan perlindungan hak perempuan dan pencegahan kejahatan terhadap perempuan yang diatur dalam rejim hukum hak asasi manusia di ASEAN. ASEAN juga membuat pernyataan pada Dewan Keamanan PBB mengenai Perempuan, Perdamaian dan Keamanan bahwa ASEAN akan memperhatikan penyelesaian kejahatan seksual terhadap perempuan dalam situasi konflik dengan mensyaratkan penyelesaian akar permasalahan yang menimbulkan bencana kemanusiaan yang dihadapi oleh pengungsi perempuan Rohingya. Akan tetapi beberapa negara ASEAN (seperti Malaysia, Indonesia dan Thailand) memiliki kebijakan sendiri dalam memperlakukan pengungsi yang menunjukan kurangnya komitmen dalam melindungi pengungsi yang

\section{PADJADJARAN Journal of Law Volume 5 Number 2 Year 2018 [ISSN 2460-1543] [e-ISSN 2442-9325]}

* This paper has been presented in the International Conference, Rise of Asia, "In the Global History and Perspective: What Local and Global Changes in the Diversity of Life", in Universite Paris 1 Phanteom, Sorbonne and Universite Le Havre Normandie, France, on March 14-16, 2018.

** Lecturer of International Law, Faculty of Law, Universitas Airlangga, Jl. Dharmawangsa Dalam Selatan Surabaya, intan@fh.unair.ac.id, S.H. (Universitas Padjadjaran), M.Hum. (Universitas Gadjah Mada), Dr. (Vrije Universeteit Brussels).
\end{abstract}


berakibat pada pengungsi perempuan. Oleh karena itu, artikel ini akan menganalisa peran ASEAN dalam melindungi pengungsi perempuan Rohingya berdasarkan komitmen ASEAN. Tujuannya adalah untuk menerapkan komitmen ASEAN dalam melindungi hak perempuan dan meningkatkan perlindungan bagi pengungsi perempuan Rohingya.

Kata kunci: hukum HAM ASEAN, pengungsi Rohingya, perlindungan pengungsi perempuan.

\section{A. Introduction}

The Rohingya conflict has led Rohingya Muslims to undertake risky journeys seeking a safe place since 1978. During 1991-1992, almost a quarter of million Rohingyas fled to Bangladesh. Approximately, almost 29.000 Rohingyas live in official refugee camps in Bangladesh where the United Nations High Commission for Refugee (UNHCR) and non-government organizations (NGOs) help them. On the other hand, about 200,000 Rohingya refugees reside in unofficial camps or Bangladesh villages, where no legal protection from arrest or abuse and no humanitarian assistances. ${ }^{1}$ Those refugees live in terrible conditions and lack of food, water, sanitation, medical care, as well as access to their livelihoods and assets. On August 25, 2017, roughly 603.000 Rohingya Refugees have crossed the border into Cox Bazar, Bangladesh; 51 percent of them are females. ${ }^{2}$ Rohingya refugees also fled to other Myanmar neighboring countries, such as Malaysia, Thailand, and Indonesia. However, the policies of these countries indicate less commitment to protect the refugees. The reluctant of some ASEAN countries to respond to Rohingya refugees gives an impact to women refugees, who are considered the most vulnerable group facing the risks of abandonment, abuse, and violence. The Rohingya conflict creates the violation of women's human rights, considering the risks of sexual violence, abduction, trafficking, and prostitution.

Association of Southeast Asian Nations (ASEAN) has made important institutional statements concerning the protection of women's right and preventing violence against women (ASEAN Human Right Declaration in 2012 and ASEAN Declaration on Elimination of Violation against Women in 2004). In addition, ASEAN also has made a statement to the Security Council on Women, Peace, and Security to address sexual violence in the conflicts that requires the tackling on the root-cause of the humanitarian disaster faced by Rohingya women refugees. The instruments are supposed to be the foundation for ASEAN members to protect women's refugees. This article attempts to analyze the ASEAN role to protect Rohingya women refugees based on ASEAN legal commitment, including the ASEAN Regime of Human Rights.

This article begins with the explanation of the refugee's policies in some ASEAN Countries particularly Malaysia, Thailand, and Indonesia.

United Nations, "UN Refugee Agency Redeploys Staff to Address Humanitarian Needs in Myanmar", https:// news.un.org/en/story/2012/06/414422-un-refugee-agency-redeploys-staff-address-humanitarian-needsmyanmar, accessed on January 2018.

2 Eilish, "Two months on: Rohingya refugee crisis", https://www.oxfam.org.nz/blogs/2017/10/26/two-monthsrohingya-refugee-crisis, accessed on February 2017. 
Their refugee's policies show the minimum pledge on the protection of refugees in general. It gives rise the minimum protection of the Rohingya women refugees. Contrariwise, ASEAN has made an important institutional statement concerning the protection of a human rights, including women's right. It opens the path to the second part of this article, which explains women's right in international human rights law regime. From the international standpoint, the international community has recognized the necessity to regulate the protection of women's rights in several agreements. One of them is the UN Charter. The third part of this article elaborates the adoption of the women's right protection from the international sphere to the ASEAN regional sphere. It shows that ASEAN has a legal commitment to transform the international idea to expand the human rights protection into more genderbased protection to prevent gender-based violence in its region. The fourth part of this article elucidates the legal commitment of protection of women's refugees as a part of the protection on women's right to the distress circumstances. The last part of this paper explains the role of ASEAN to protect Rohingya women refugees by strengthening the existence of its human rights commission for women or the ASEAN Commission for the Promotion and Protection of Women and Children (ACWC).

This article sheds light on the issue of Rohingya women refugees and the significant role of ASEAN to protect women's rights and to prevent violation, considering that up to nowadays, the issue of Rohingya women's refugees is still unresolved. This article tries to enrich the literature of the protection of women refugees.

This study is a normative legal research, and employed the statute approach. The approach analyzes and examines International Human Rights Law related to the protection on women's rights in ASEAN Laws. The ASEAN Laws include the ASEAN Declaration of Human Right (adopted on November 19, 2012 in Phnom Penh), the ASEAN Declaration on the Elimination of Violence Against Women in the ASEAN Region (2004), The Declaration on the Elimination of Violence against Women and Elimination of Violence Against Children (2013), ASEAN Regional Plan of Action on the Elimination of Violence Against Women (2015), Joint Statement on Promoting Women, Peace and Security in ASEAN $(2017)^{3}$, and the Convention against Human Trafficking.

\section{B. The Refugees policies of Malaysia, Thailand, and Indonesia that affect Rohingya Women Refugees}

Waves of Rohingya refugees have fled to some ASEAN countries such as Malaysia, Thailand, and Indonesia because the countries are close to Myanmar geographically. The countries have considerable experiences of providing shelter to refugees. ${ }^{4}$

ASEAN, "Overview - Asean | One Vision One Identity One Community", http://asean.org/asean-socio-cultural/ asean-ministerial-meeting-on-women-ammw/ov, accessed on February 2018.

4 B. Singh, "ASEAN, Myanmar and the Rohingya Issue", Himalayan and Central Asian Studies, Vol. 18, Issue 1, 2014, pp. 5-20. 
However, most of ASEAN members are reluctance to recognize the refugees' status. ${ }^{5}$ Malaysia, Thailand, and Indonesia do not ratify the UN Refugee Convention, (the Philippines has ratified it in 1988). These countries refused to sign the Refugee Convention due to the perceptions that refugee is a political problem ${ }^{6}$ and the refugees are 'threat to border' security. ${ }^{7}$

Malaysia, for example, provides shelters for refugees since 1970s. ${ }^{8}$ This country is hosting about 154.140 refugees; and 53.410 of them are the Rohingyas. ${ }^{9}$ However, due to "heavy financial burden" and "the huge presence of refugees or asylumseekers may threat the national security," ${ }^{10}$ Malaysia does not ratify the Refugee Convention. Malaysia does not recognize the status of refugees. It has introduced the 2000 Immigration Act, subjecting the Rohingya refugees to arrest, detention, and refoulement. Moreover, during 2015, Malaysia often responded the refugees who arrived by boats to their coast by punitive measures. ${ }^{11}$

Thailand has an almost similar policy toward the Rohingya refugees. In 1999, the Thailand Government issued the Provincial Admissions Boards to screen asylumseekers. This policy only admits the people who fled because of political reason, not because of fighting and civil war or fearful of persecution. ${ }^{12}$ In 2015, the Deputy Prime Minister of Thailand stated that the government would take legal action on the refugees who enter Thai waters as illegal immigrants. However, if they decide to continue to a third country, the Thai Government will provide all necessary efforts to support them to leave to the third country. ${ }^{13}$

Unlike Malaysia and Thailand, Indonesia tends to serve as a transit country. Refugees are classified as illegal migrants, unless they come under the 2001 Regional Cooperation Mode, an agreement between Australia, Indonesia, and the International Organization for Migration (IOM). In 2010, the Indonesian Director General of Immigration issued a directive that allows migrants to stay in Indonesia temporarily if they have attestation letter verifying that they are seeking asylum from UNHCR or they received recognition of refugee status from UNHCR. However,

5 Susan Kneebone, "ASEAN and Conceptualization of Refugee Protection in Southeastern Asian States", in Ademola Abass and Francesca Ippolito (eds.), Regional Approach to The Protection of Asylum Seeker: An International Legal Perspective, New York: Routledge, 2016, p. 297.

6 GS. Goodwin-Gill, “The Politics of Refugees Protection”, Refugee Survey Quarterly, No. 27, Issue 1, 2008, p.8. Susan Kneebone, loc.cit.

Amarjit Kaur, "Refugees and Refugee Policy in Malaysia", UNEAC Asia Papers, No. 18, 2007, pp. 77-90.

UNHCR, "Figures at a Glance", http://www.unhcr.org.my/about us-@-figures at a glance.aspx, accessed on February 2018.

10 Penelope Matthew and Tristan Haley, "Refugee Protection and Regional Cooperation in Southeast Asia: A Fieldwork Report", http://www.mcrg.ac.in/WC 2015/Reading/D RefugeeProtection.pdf, accessed on December 2017.

11 Agence France-Presse, "Malaysia to allow thousands of refugees to work to solve labour crunch", http:// reliefweb.int/report/indonesia/malaysia-allow-thousands-refugees-work-solve-labour-crunch, accessed on February 2018.

12 Sebastien Moretti, "The Challenge of Durable Solutions for Refugees at the Thai-Myanmar Border", Refugee Survey Quarterly, Vol. 34, No. 3, 2015, p. 74.

13 Tanakorn Sangiam, “DPM stressed local authorities practices for Rohingya refugees”, http://thainews.prd. go.th/website en/news/news detail/WNPOL5805180010012, accessed on June 2017. 
this process takes a certain length of time. Those who do not possess documents will be subjects to detention. ${ }^{14}$

The refugee's policies in Malaysia, Thailand, and Indonesia indicate the reluctance of these countries to respond the Rohingya refugees seriously. The Rohingya refugees face difficulties to seek protection in these countries. Subsequently, it surely affects Rohingya women refugees. Some of these women were raped or experienced violence forcing them to leave Myanmar during 1991-1992. Even after the exodus, these women refugees are still at risk of sexual violence, abduction, trafficking, and prostitution in the refugee's camps. ${ }^{15}$ For example, UNICEF reports that no less than 500 women refugees in Kutopalong Camp work as prostitutes to earn basic needs, such as bread and rice. ${ }^{16}$ This situation shows that Rohingya women refugees are seeking the protection from the violation of their human rights, rather than for any political reasons. It then urges an urgent call for the realization of refugee protection, especially for women. ASEAN members should realize that the cause of Rohingya conflict is human-rights violations.

ASEAN members should realize that the human rights crisis in Rohingya has become a notorious condition after it is developed into gender-based violence. The situation is complex for Rohingya women because the violence took severe forms. The conflict has brought effects on women's rights. The violence has caused Rohingya women to flee as refugees. The displacement of Rohingya women also has created a vulnerable situation. They are still being victims of gender-based violence, such as rape, trafficking, sexual slavery, prostitution, or forced-marriage. ${ }^{17}$

Taking a stance from the point of view that the major problem is the violation of human rights, this article analyzed the legal basis to protect the women's rights. it also provides some arguments for the role of ASEAN countries to protect Rohingya women refugees.

\section{Legal Basis of Protection on Women's Rights in International Human Rights Law}

International law recognizes the protection of women's rights in the UN Charter 1945 concerning the right to equal treatment and non-discrimination. ${ }^{18}$ This protection develops in the Universal Declaration of Human Rights that also prohibits

14 Mary Crock, "Shadow Plays, Shifting Sands and International Refugee Law: Convergences in the Asia Pacific", International \& Comparative Law, Vol. 63, Issue 2, 2014, p. 260.

15 See Images Asia, Trafficked from Hell to Hades: The Plight of Rohingya Women from Burma Trafficked in Pakistan, Makati: Images ASIA , 1999.

16 Stefanie Glinski, "Clandestine sex industry booms in Rohingya refugee camps", https://www.reuters.com/ article/us-bangladesh-rohingya-sexworkers/clandestine-sex-industry-booms-in-rohingya-refugee-campsidUSKBN1CS2WF, accessed on July 2018.

17 Rashida Manjoo and Calleigh McRaith, "Gender-based violence and justice in conflict and post-conflict areas", Cornell International Law Journal, Vol. 44, No. 11, 2011, pp. 11-12.

18 Charlesworth H., "Inside/outside: women and the international human rights system", in Constantinides A. and Zaikos N (eds.), The Diversity of International Law. Leiden-Boston: Martinus Nijhoff Publishers, 2009, pp. 381-398. 
discrimination of the rights. ${ }^{19}$ The prohibition of gender-based discrimination also enshrines in the International Covenant on Civil and Political Rights (ICCPR) and the International Covenant on Economic, Social, and Cultural Rights (ICESCR). The ICCPR emphasizes the right to life, freedom from torture, freedom from slavery, the right to liberty, and security of person, rights in legal proceedings, and rights related to political freedom. ${ }^{20}$ Some of ICCPR articles confront violence against women. Article 7 says, "No one shall be subjected to torture or to cruel, inhuman or degrading treatment or punishment. In particular, no one shall be subjected without his free consent to medical or scientific experimentation". Article 9 reads, "Everyone has the right to liberty and security of person". The last, Article 27 mentions, "In those States in which ethnic, religious or linguistic minorities exist, persons belonging to such minorities shall not be denied the right, in community with the other members of their group, to enjoy their own culture, to profess and practise their own religion, or to use their own language". ${ }^{21}$ The ICESCR promulgates the protection of women's right in the form of equal treatment between men and women in economic, social, and culture.

The most significant international legal instrument for the protection of women's rights enshrines in the Convention on the Elimination of all forms of Discrimination against Women (CEDAW). ${ }^{22}$ CEDAW articulates the obligations for states members to eliminate discrimination and to achieve substantive equality, in not only laws and regulations, but also in practices, customs, and private actors. ${ }^{23}$ CEDAW also recognizes the prohibition of gender-based violence as a form of discrimination against women. ${ }^{24}$ It leads to the Declaration on the Elimination of Violence against Women. The term of violence against women means any act of gender-based violence that results in, or is likely to result in, physical, sexual, or psychological harm or suffering to women, including threats of such acts, coercion, or arbitrary removal of liberty, whether in public or in private life. ${ }^{25}$ In this point, gender-based violence could be a significant point to examine the violence against women because the nature of violence against women is a gender-based violence.

The gender-based violence also could happen in the peacetime, for instances in the cases domestic violation, sexual coercion, and abuse. According to a recent review of fifty populations-based studies in 36 countries, $10 \%$ to $60 \%$ women have experienced at least one physical violence. ${ }^{26}$ Gender-based violence, such as sexual

19 Johannes Morsink, "Women's rights in the Universal Declaration", Human Rights Quarterly, Vol. 13, No. 2 , 1991, p. 64. See also Article 2 of the Universal Declaration of Human Rights 1948 (UDHR).

20 See the International Covenant on Civil and Political Rights 1966 (ICCPR).

21 Ibid.

22 See Convention on the Elimination of all forms of Discrimination against Women 1981 (CEDAW). See also United Nations Human Rights Office of the High Commissioner (OHCHR), "Women's Rights are Human Rights", http:// www.ohchr.org/Documents/Publications/HR-PUB-14-2.pdf, accessed on January 2018.

23 Article 2(e), 2(f), 3, 5, and 6 of CEDAW.

24 General Recommendation No 19 (n 35) paras 1 and 6 of CEDAW.

25 Article 1 of the United Nations General Assembly Resolution A/RES/48/104.

26 Heise L, Ellsberg M, and Gottemoeller M, "Ending violence against women”, Population Reports, Series L, No. 11, 1999, p. 213. 
violence, towards women also often occurs during conflict time. Conflict potentially increases the scale and the level of violence. The impact possibly extends to postconflict period. ${ }^{27}$ The protection of human security during and after conflicts is an issue to address. ${ }^{28}$ Consequently, in 2000, the UN Security Council started to adopt the UN Security Council Resolution 1325 on Women, Peace, and Security (Resolution 1325). The Resolution 1325 considers earlier activities when the international community redefines violence against women as a human rights issue..$^{29}$ It recognizes the devastating impact of conflicts on women and reaffirms the need to implement existing international humanitarian and human rights law to protect women's right during and after conflict. ${ }^{30}$ Hence, the focus of Resolution 1325 is to prevent, to participate, to protect, to relief, and to recover women by taking specific measures. It also focuses on the punishment for perpetrator who is responsible for crime during conflict. The resolution also urges for increased representation of women at all levels of decision-making and all mechanism for the prevention, management, and resolution of conflict and peacekeeping operation. ${ }^{31}$ It was resulted from a number of advocacy efforts and international agreements to protect women's rights, such as the Convention on the Elimination of All Forms of Discrimination against Women (1979), the Beijing Declaration and Platform for Action (1995), the Windhoek Declaration, and the Namibia Plan of Action on Mainstreaming a Gender Perspective in Multidimensional Peace Support Operations (2000). ${ }^{32}$

The international human rights laws are focused mainly on the protection of women rights under any circumstances. The Refugee Convention has a genderneutral nature since it refers to the protection of all refugees, both men and women. However, the violence against women is not only a result during a conflict. It also occurs after the conflict. Women need protection to get to their normal lives.

In some cases, women cannot have an equal status with men because armed conflict often cause discrimination and violence against them. ${ }^{33}$ Therefore, the UNHCR issued an Agenda for the Protection of Women Refugees in 1985. ${ }^{34}$

$27 \quad$ Allys M. Willman and Crystal Corman, "Sexual and Gender Based-Violence: What is the World Bank Doing and What We Have Learned", A Strategic Review, 2013, p. 20.

28 R. Charli Carpenter, "Recognizing Gender-Based Violence Against Civilian Men and Boys in Conflict Situation", Security Dialogue, Vol. 37, No. 1, 2006, p. 83.

29 Jutta Joachim, "Framing Issues and Seizing Opportunities: The U.N, NGOs and Women's Rights", International Studies Quarterly, Vol. 47, Issue 2, 2003, pp. 247-274.

30 OHCHR, "Women's Rights are Human Rights", loc.cit.

31 Office of the Special Adviser to the Secretary-General on Gender Issues and Advancement of Women (OSAGI), "Landmark resolution on Women, Peace and Security", http://www.un.org/womenwatch/osagi/wps/, accessed on January 2018.

32 Sahana Dharmapuri, "Implementing UN Security Council Resolution 1325: Putting the Responsibility to Protect into Practice", Global Responsibility to Protect, Vol, 4, Issue 2, 2012, pp. 241-271.

33 Women, Peace and Security, "Study Submitted by the Secretary-General pursuant to Security Council Resolution 1325", http://www.un.org/womenwatch/daw/public/eWPS.pdf, accessed on February 2018, para. 6.

34 See United Nations High Commissioner for Refugees (UNHCR) Executive Committee Conclusions on the Refugee Women and International Protection No. 39 (XXXVI) 1985. 
The Executive Committee of the Higher Commissioner Program states that female refugees constitute the majority population of the world refugees; and that they are exposed to many problems related to international protection. These problems are resulted by their vulnerable situations. The situations frequently expose them to physical violence, sexual abuse, and discrimination. The program urges the governments and the UNHCR to undertake all appropriate measures to guarantee the protection of female refugees from violence or threats. In addition, the program also urges the states, in their sovereignty, to consider female asylum-seekers, who face harsh or inhuman treatments, as a 'particular social group' that needs protection under the 1951 UN Refugee Convention. ${ }^{35}$ In 1991, UNHCR issued a Guideline on the Protection of Refugee Women that has been an important tool for UNHCR staffs and partners to protect the rights of female refugees and to solve some related problems. The guideline also elaborates the measure to protect refugees by assisting and emphasizing the importance of women participation in the decisionmaking and planning processes. ${ }^{36}$

\section{Legal Commitment to the Protection of Women's Right in ASEAN}

The issue of women's right is shifting constantly from international to regional level. De Vido argues that "the shifting focus from the international to regional level should be stressed by the regionalization of the protection of women's right as a response to the challenge stemming from the peculiarities of the society." ${ }^{37}$ ASEAN has its uniqueness in its policy towards human rights protection, especially women's rights. The intention to transform the international idea of protection on women's rights is indicated in ASEAN laws.

Previously, Bangkok Declaration, the legal foundation of ASEAN, only concerns with national security protection, not the genuine implementation of human rights protection. ${ }^{38}$ up to 1988, ASEAN transformed the idea of human rights protection, especially women's rights, into the Declaration of the Advancement of Women in the ASEAN Region. ASEAN, hence, manifested its commitment to the protection of women's and children rights in the region. ${ }^{39}$ Furthermore, all ASEAN states have bound themselves into the Convention on the Elimination of All Forms of Discrimination against Women (CEDAW).

\footnotetext{
Ibid.

36 UNHCR, "Handbook for the Protection of Women and Girls, Provisional Release for Consultation Purposes", http://www.unhcr.org/protection/women/47cfa9fe2/unhcr-handbook-protection-women-girlsfirst-edition-complete-publication.html, accessed on February 2018.

37 Sara de Vido, “Recognizing Gender-Based Violence Against Civilian Men and Boys in Conflict women's Rights and Gender Equality in Europe and Asia", in Yumiko Nakanishi (ed.), Contemporary Issues in Human Right Law: Europe and Asia, Singapore: Springer Open, 2018, p. 148.

38 See Vitit Muntarbhorn, Legal Cooperation among ASEAN Countries, Bangkok: Institute of Security and International Studies, 1997.

39 Association of the South East Asia Nations (ASEAN), Declaration of the Advancement of Women in the ASEAN Region 1988, http://asean.org/?static post=declaration-of-the-advancement-of-women-in-the-asean-regionbangkok-thailand-5-july-1988, accessed on January 2018.
} 
Since all ASEAN members are the parties of CEDAW, it means that ASEAN has a common concept regarding the violation of women's rights. ${ }^{40}$ In 1993, in the Vienna World Conference on the Human Rights, the ASEAN's Foreign Ministers responded to the specific calls made by the UN to promote regional human rights mechanism in the Asian region. ${ }^{41}$ It headed to the creation of the ASEAN Intergovernmental Commission on Human Right (AICHR). More specific for women's right, ASEAN has established the ASEAN Commission for the Promotion and Protection of Women and Children (ACWC).

The protection of human rights is included in ASEAN Charter. It requires all ASEAN members to adhere to the principles of democracy, the rule of law and good governance, respect for and protection of human rights and fundamental freedom. ${ }^{42}$ It had encouraged ASEAN to make the ASEAN Human Right Declaration (AHRD) that is started to be adopted on November 18, 2012. AHRD states, "The rights of women, children, the elderly, persons with disabilities, migrant workers, and vulnerable and marginalized groups are an inalienable, integral and indivisible part of human rights and fundamental freedoms." ${ }^{43}$ Following the adoption of AHRD, the ASEAN members adopted the ASEAN Declaration on the Elimination of Violence against Women and Violence against Children on October 9, 2013. ${ }^{44}$ Subsequently, the ASEAN Declaration on the Elimination of Violence against Women (ADEVW) followed it in 2004. The ADEVW, like all other ASEAN human rights documents, is only a declaration. It merely gives recommendation and does not bind ${ }^{45} \mathrm{As}$ a result, the Declaration must be read together with the ASEAN Regional Plan of Action (RPA) on the Elimination of Violence against Women, adopted in November 2015. The RPA is a concrete action of ASEAN to imply the protection of women's rights.

Under the RPA, ASEAN members should promote the rights of women and children; and should prevent and protect them from, and respond to, all types of violence, abuse, and exploitation. It particularly covers them who are in vulnerable situations. The protection covers women and children in armed conflicts, in refugee camps, on the movements, in stateless status, migrant, and they who belongs to ethnic and/or indigenous groups. ${ }^{46}$ ASEAN members are committed to respond to the violation of women and children's rights, especially they who are in vulnerable situations such as armed conflicts, post-conflicts, and refugees.

40 UN Committee on the Elimination of Discrimination against Women, General Recommendation No. 19, $11^{\text {th }}$ session, 1992, para. 6.

41 A. Langlois, "Asian Regionalism and Human Rights", in M. Beeson and R. Stubbs (eds), Routledge Handbook of Asian Regionalism, New York: Routledge, 2012, p. 216.

42 See ASEAN Charter 2008 (ASEAN Charter).

43 See ASEAN Declaration of Human Rights 2012 (AHRD).

44 The text of the Declaration is available at http://www.ohchr.org/Documents/Issues/Women/WG/ ASEANdeclarationVaW violenceagainstchildren.pdf, accessed on February 2018.

45 Tan Hsien-Li, The ASEAN Intergovernmental Commission on Human Rights: Institutionalizing Human Rights in ASEAN, Cambridge: Cambridge University Press, 2011, p. 177.

46 Ibid., see also United Nations Children's Fund (UNICEF), "UNICEF and Jawwal reach more than half a million people in Gaza with life-saving and child protection messages", https://www.unicef.org/oPt/media 9557.html, accessed on February 2018. 


\section{E. ASEAN Legal Commitment for the Protection of Rohingya Women Refugees}

Some ASEAN members like Malaysia, Thailand, and Indonesia already have policies regarding refugees. However, the case of Rohingya is unique and complex. Therefore, ASEAN should focus on the root-cause of the migration of the Rohingya people, including the women. The root-cause is a conflict that triggered gender-based violence. The violence occurred because the people of Rohingya are very vulnerable due to their low socio-economic status. Ethnic discrimination by Myanmar also has contributed to the violence. ${ }^{47}$

During the process of displacement, the Rohingya women are often subjects to physical and sexual attacks, rape, and another form of sexual harassment. These women refugees are also vulnerable to abduction and trafficking. The genderbased violence even continued until they arrive in the refugee camps. The security situation in the refugee camps does not guarantee that the refugees, especially women and children, will be free from violence and bad situation. For instances, the distance and position of latrines, bathrooms, and water sources may undermine their privacy and security. The lights of the camps sometimes make their move in night and evening unsafe. ${ }^{48}$ They are also vulnerable to prostitution and forcedmarriage. These situations occur because they are vulnerable and unprotected. The women refugees are experiencing gender-based violence during and after the conflict. Therefore, all ASEAN governments need to pay attention because, principally, ASEAN has legal commitments to the protection of women's rights, such as the 2004 ASEAN Declaration on the Elimination of Violence against Women and the 2013 Declaration on the Elimination of Violence against Women and Violence against Children in ASEAN. ASEAN also has added two regional commitments that can be the legal basis for the protection of Rohingya Women Refugees: The Joint Statement from ASEAN to Promote Women, Peace, and Security; and the ASEAN Convention against Human Trafficking.

\section{ASEAN Joint Statement to Promote Women, Peace, and Security}

ASEAN has a joint statement to promote women, peace, and security in ASEAN Region. ${ }^{49}$ In the statement, ASEAN aims to eliminate violence against women and girls according to the ASEAN human rights regime. ${ }^{50}$ ASEAN also concerns the

47 Mizzima News, “Burma: Amid Praise, End to Sexual Violence: G8”, http://www.mizzima.com/news/world/9219amid-praise-end-to-sexual-violence-g8, accessed on February 2018.

48 Report Medecins sans Frontieres, "10 Years for the Rohingya Refugees In Bangladesh: Past, Present and Future", http://www.msf.org/en/article/ten-years-rohingya-refugees-past-present-and-future-report-summary, accessed on December 2017.

49 ASEAN, Joint Statement on Promoting Women, Peace, and Security in ASEAN 2017, http://asean.org/ storage/2017/11/8.-ADOPTION Joint-Statement-on-Promoting-Women-Peace-and-Security-in-ASEANACWCEndorsed rev2.pdf, accessed on December 2017.

50 See also Declaration on the Elimination of Violence Against Women in the ASEAN Region 2004; Declaration on the Elimination of Violence against Women and Elimination of Violence Against Children 2013; Ha Noi Declaration on the Enhancement of the Welfare and Development of ASEAN Women and Children 2010; and the ASEAN Regional Plan of Action on the Elimination of Violence Against Women 2015. 
increasing and unprecedented threats posed by conflicts, the rises of violent extremism, and the increasing numbers of refugees and displaced individuals. In this regard, ASEAN continues to address women's rights violation because of conflicts or any precarious situations.

The ASEAN Ministerial Meeting on Women is the recent development in creating a mechanism of ASEAN that institutionalizes gender mainstreaming. It encourages all ASEAN members to promote women's status at the regional level. ${ }^{51}$ The mechanism should work in conjunction with the ASEAN Commission on the Promotion and Protection of the Rights of Women and Children (ACWC) as a part of regional human rights mechanism. ${ }^{52}$ ACWC is an intergovernmental commission and an integral part of the ASEAN organization. Each ASEAN member has two representatives for women and children. The function of ACWC is to promote and to protect human rights and fundamental freedom of women and children in the ASEAN Region. ${ }^{53}$ Before the establishment of ACWC, ASEAN also established the ASEAN Committee on Women (ACW) in 1976. ACW is an ASEAN sectoral body. Its mandates are to implement, to coordinate, and to monitor the implementation of ASEAN's key regional priorities and cooperation on women issues. The function of ACW has highlighted the increasing incidents of discrimination and violence against women of indigenous/ethnic minority, women with disabilities, and women from diverse groups. ${ }^{54}$

Related to the implementation of UN Security Council Resolution 1325, ACWC should have a correct function to promote peace and security for Rohingya women refugees since ACWC mandates to promote the implementation of international, ASEAN, and other instruments concerning the rights of women and children. ${ }^{55} \mathrm{It}$ means that ACWC should promote UN Security Council Resolution on Women, Peace, and Security to encourage ASEAN to protect Rohingya women refugees.

The implementation of UN Security Council Resolution on Women, Peace, and Security Agenda is relevant to support and to strengthen the current ASEAN human rights regime. The states need to prevent, to participate, to protect, to relief, and to recover women by taking special measures protecting women from the genderbased violence. The ACWC can work based on the Regional Plan of Action on the Elimination of Violence against Women (RPA) in taking special measures to protect Rohingya women refugees from gender-based violence after the conflict, both in the refugee camps or in any provided settlements.

ASEAN, "ASEAN Ministerial meeting on Women". http://www.asean.org/communities/asean-socioculturalcommunity/ category/asean-ministerial-meeting-on-women-ammw, accessed on January 2018.

52 Soukphaphone Phanit, "The Relationship Between The Lao People's Democratic Republic (Lao PDR) and the ASEAN Commission for the Promotion and Protection of the Rights of Women and Children (ACWC) with a focus on women," http://unitec.researchbank.ac.nz/handle/10652/2318, accessed on February 2018.

53 Ibid.

54 Ibid.

55 Sara E. Davies, "Women, peace and security as an ASEAN priority", Australian Journal of International Affairs, Vol. 68, No. 3, 2014, pp. 333-355. 


\section{The ASEAN Convention Against Human Trafficking Targeting Women and Children}

One of the impacts of the Rohingya conflict is human trafficking. The on-going statesponsored persecution of the Rohingya people leads to the displacement of the Rohingya population that makes them vulnerable to human trafficking. The Rohingya women refugees are fragile and unprotected. It becomes another issue of women's rights violation then.

The prevention and prohibition of human trafficking is regulated by the UN Protocol to Prevent, Suppress, and Punish Trafficking in Person, especially Women and Children (UN Protocol). It is a supplement to the UN Convention Against Transnational Organized Crime in 2000.56 The UN Protocol defines trafficking as the element of offences and conducts. The obligation of UN members is to punish the perpetrators. ${ }^{57}$ Almost all ASEAN members, except Brunei Darussalam, have ratified the UN Protocol. It then leads to the ASEAN Ministerial Meeting in the $27^{\text {th }}$ ASEAN Summit, in 2015. The meeting adopted the ASEAN Convention against Human Trafficking in Persons, Especially Women and Children. Nowadays, the Convention has been established. The convention addresses regional challenges, which are common to all ASEAN members, to identify and to imply (1) prevention of trafficking in persons; (2) Protection of victims; (3) law enforcement and prosecution of crimes of trafficking in persons; and (4) Regional and International cooperation and coordination. ${ }^{58}$

The convention should be read and implied together with the ASEAN Plan of Action against Trafficking in Persons, especially Women and Children. The Plan of Action begins with the alleviation of all the factors that make persons, especially women and children, vulnerable to trafficking. These factors are organized crime, government corruption, poverty, different social levels, economic development, economic instability, inefficient law enforcement and legal system, and discouraging the demand that fosters all forms of exploitation of persons, especially women and children, that leads to trafficking. ${ }^{59}$ Moderately, ASEAN can seek solutions by bringing this convention on the negotiation with the Myanmar government to alleviate the factor of human trafficking because of Rohingya conflict. The idea emanates in the objective of the Regional Plan of Action is that all ASEAN members need to address the challenges effectively, to prevent progressively, to suppress and to punish all forms of trafficking in persons towards an enhanced comprehensive and coordinated regional approaches to achieve the objective.

\footnotetext{
Chapter XVIII, Penal Matters, No 12. on Protocol to Prevent, Suppress and Punish Trafficking in Persons, Especially Women and Children, supplementing the United Nations Convention against Transnational Organized Crime 2000.

57 Anne T. Gallagher, The International Law of Human Trafficking, Cambridge: Cambridge University Press, 2010, p. 215.

58 See ASEAN Convention Against Trafficking in Persons, Especially Women and Children 2015.

59 See ASEAN Plan of Action Against Trafficking in Persons, Especially Women and Children 2015.
} 

Rohingya Women Refugees ${ }^{*}$

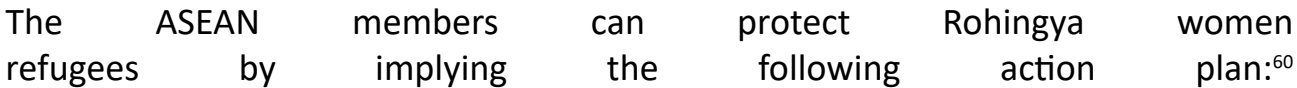

(1) strengthening the rule of law and border control among the ASEAN members;

(2) intensifying efforts to prosecute trafficking in person case; and

(3) strengthening regional cooperation based on shared responsibilities to address effectively the demand and the supply that fosters all forms of trafficking in person, especially women and children.

These legal commitments are the ASEAN human rights instruments that can be applied in handling the protection of Rohingya women refugees. The major role of ASEAN in protecting Rohingya women's refugees appears to a benefit of the ASEAN legal commitment on the protection of women's rights in ADEVW and its RPA. ASEAN can strengthen its role to protect the Rohingya women refugees also by applying the UN Security Council Resolution 1325 and the ASEAN Plan of Action against Trafficking in Persons, especially Women and Children.

\section{F. The Role of ASEAN to protect Rohingya Women Refugees}

The legal commitments to protect women's right that are promulgated in the ASEAN Human Rights regime, such as the ADEVW, should be read together with the Regional Plan of Action (RPA) on the Elimination of Violence against Women. The RPA is a demonstration of the ASEAN members commitments to support the implementation of ADEVW and the Joint Statement of Women, Peace, and Security, which are consistent with the contents of the ASEAN Human Rights Declaration.

The objective of RPA is divided into two. The first, ASEAN institutionalizes the policies of the elimination of violation against women and sustainment support across all pillars and sectors. The second, each ASEAN members has effective prevention and protection services supported by national legal frameworks and institutional mechanisms. The RPA adopts some strategies. They cover effective and coordinated strategies to prevent violence, protecting victims/survivors of violence, developing and strengthening legal frameworks, strengthening the capacity of individuals and institutions, collecting data and monitoring the efforts through periodic review. ${ }^{61}$ The ACW and the ACWC imply a joint effort to implement the RPA in line with their respective Terms of Reference and work plans.

ASEAN needs to support ACW and ACWC to prevent, to protect, and to support services for Rohingya women refugees based on the RPA.

\section{The Prevention}

The ACW should ensure the prevention of all forms of violence against women, in particular the sexual violence with all humanitarian response assistance. The term sexual violence covers all physical, sexual, and psychological harmful actions

$60 \quad$ Ibid.

61 See ASEAN Regional Plan of Action on the Elimination of Violence against Women 2015 (ASEAN RPA on EVAW). 
perpetrated or condoned by state and non-state entities, wherever it occurs. ${ }^{62}$ In the case of Rohingya women, ACW can coordinate with humanitarian actors to support the establishment and implementation of interventions to protect women from all forms of gender-based violence including sexual exploitation and abuse. ${ }^{63}$

\section{Protection}

The ACW can incorporate the prevention of and response to all forms of violence against women into the planning and the delivery of disaster-risk reduction programs and protocols following conflict situation, natural disasters, or other emergencies. ${ }^{64}$ Regarding Rohingya women, the ACW can coordinate with humanitarian actors from donor countries and the UN to impose humanitarian aids. They can assist and alleviate refugees suffering, including the specific risks faced by women. ${ }^{65}$ The task can implement gender-sensitive refugees processing mechanisms to collect data on women entering camps, deploying trained female interpreters and health workers, and protecting female refugees from additional violence.

\section{Support service for victims/survivor}

One of the RPA strategies is to provide multi-disciplinary and coordinated response service for victims/survivors through an integrated support system. They system includes, but is not limited to, medical and psychological care, counselling services, legal aid, interpretation and translation services, accommodation, and other supports. This strategy can be applied to protect Rohingya women refugees, together with international humanitarian actors such as the UN Agency and the non-government organizations.

The actions will be useless without supports from all ASEAN members. The most important part is that ASEAN members must have political wills to resolve the human rights crisis involving Rohingya Women according to the ASEAN Declaration on Human Rights. The ADHR underlines the necessity for ASEAN Members to cooperate to promote and to protect human rights.

"The ASEAN Member States share a common interest in and commitment to the promotion and protection of human rights and fundamental freedoms which shall be achieved through inter alia, cooperation with one another as well as with relevant national, regional and international institutions in accordance with ASEAN Charter." 66

62 See United Nations Entity for Gender Equality and the Empowerment of Women (UN Women) Beijing Declaration and Platform for Action 1995.

63 UN Women, "Gender Briel on Rohingya Refugees Crisis", http://asiapacific.unwomen.org/en/digital-library/ publications/2017/10/gender-brief-on-rohingya-refugee-crisis, accessed on January 2018.

64 See ASEAN RPA on EVAW.

65 Council on Foreign Relations, "Women and Girls at Risk In The Rohingya Refugee Crisis", https://www.cfr.org/ blog/women-and-girls-risk-rohingya-refugee-crisis, accessed on February 2018.

66 See ADHR; and Asean Trade Union Council, "Vietnam Affirms ASEAN S Commitment to Human Rights", http:// aseantuc.org/2014/03/vietnam-affirms-aseans-commitment-to-human-rights/, accessed on February 2018. 
Based on this legal commitment, ASEAN members should seek solutions to cease the human rights crisis involving Rohingya women refugees. ASEAN Members can impose following efforts:

1. Persuading the Myanmar government to allow access for ASEAN

Representatives and humanitarian actors providing humanitarian assistance and bridging the gap between Myanmar and the international community to facilitate effective distribution of assistance.

1. Playing active role to negotiate with the Myanmar government to cease the human rights violation in the Rakhine Province and to provide the safe place for the repatriation program.

2. ASEAN Members could provide temporary shelter and work together with international humanitarian agents to provide camps.

3. Sharing responsibility by tackling the human trafficking resulted from the displacement of the Rohingya people and urging ASEAN members to imply the ASEAN Convention Against Trafficking in Persons especially Women and Children in their national laws.

\section{G. Conclusion}

The women are the most vulnerable group of Rohingya refugees because they have experienced and are facing gender-based violence during and after they becoming refugees or during their settlement in the refugee camps. The Rohingya women refugees are seeking safe place from the violation of their human rights to several countries, including Myanmar's fellow ASEAN members. Unfortunately, some ASEAN members (such as Malaysia, Thailand, and Indonesia) signify less commitment to protect the women refugees. Meanwhile, ASEAN has legal commitments of the protection of women's rights, including the protection of women in displacement or refugees. The explanation of the legal commitments of ASEAN human rights regime shows that there are obligations of ASEAN members to protect Rohingya women refugees because their crisis is a human rights violation. ASEAN countries can play a significant role in preventing, protecting, or responding to the gender-based violence according to ASEAN legal commitments on the protection of women's rights. All ASEAN members can impose efforts to cease the gender-based violence for protecting Rohingya women refugees.

The most important thing is the "real action" on the implementation of RPA to prevent, to protect, and to respond to the gender-based violence experienced by the Rohingya women refugees. This action can be success if all ASEAN members are committed to realize their legal commitments on the protection of women's right.

\section{References}

Books

A., Constantinides and Zaikos N (eds.), The Diversity of International Law, Martinus 
Nijhoff Publishers, Leiden-Boston, 2009.

Abass, Ademola and Francesca Ippolito (eds.), Regional Approach to The Protection of Asylum Seeker: An International Legal Perspective, Routledge, New York, 2016. Hsien-Li, Tan, The ASEAN Intergovernmental Commission on Human Rights: Institutionalizing Human Rights in ASEAN, Cambridge University Press, Cambridge, 2011.

Images Asia, Trafficked from Hell to Hades: The Plight of Rohingya Women from Burma Trafficked in Pakistan, Images ASIA, Makati, 1999.

Muntarbhorn, Vitit, Legal Cooperation among ASEAN Countries, Institute of Security and International Studies, Bangkok, 1997.

Nakanishi, Yumiko, (ed.), Contemporary Issues in Human Right Law: Europe and Asia, Springer Open, Singapore, 2018.

\section{Other Documents}

Agence France-Presse, "Malaysia to allow thousands of refugees to work to solve labour crunch", http://reliefweb.int/report/indonesia/malaysia-allowthousands-refugees-work-solve-labour-crunch, accessed on February 2018.

ASEAN Trade Union Council, "Vietnam Affirms ASEAN's Commitment to Human Rights", http://aseantuc.org/2014/03/vietnam-affirms-aseans-commitment-tohuman-rights/, accessed on February 2018.

ASEAN, "ASEAN Ministerial Meeting on Women". http://www.asean.org/ communities/asean-socio-culturalcommunity/ category/asean-ministerialmeeting-on-women-ammw, accessed on January 2018.

ASEAN, "Overview - Asean | One Vision One Identity One Community", http:// asean.org/asean-socio-cultural/asean-ministerial-meeting-on-women-ammw/ ov, accessed on February 2018.

Carpenter, R. Charli, "Recognizing Gender-Based Violence Against Civilian Men and Boys in Conflict Situation", Security Dialogue, Vol. 37, No. 1, 2006.

Council on Foreign Relations, "Women and Girls at Risk In The Rohingya Refugee Crisis", https://www.cfr.org/blog/women-and-girls-risk-rohingya-refugee-crisis, accessed on February 2018.

Crock, Mary, "Shadow Plays, Shifting Sands and International Refugee Law: Convergences in the Asia Pacific", International \& Comparative Law, Vol. 63, Issue 2, 2014.

Davies, Sara E., "Women, Peace and Security as an ASEAN priority", Australian Journal of International Affairs, Vol. 68, No. 3, 2014.

Dharmapuri, Sahana, "Implementing UN Security Council Resolution 1325: Putting the Responsibility to Protect into Practice", Global Responsibility to Protect, Vol, 4, Issue 2, 2012. 
Eilish, "Two months on: Rohingya refugee crisis", https://www.oxfam.org.nz/ blogs/2017/10/26/two-months-rohingya-refugee-crisis, accessed on February 2017.

Glinski, Stefanie, "Clandestine sex industry booms in Rohingya refugee camps", https://www.reuters.com/article/us-bangladesh-rohingya-sexworkers/ clandestine-sex-industry-booms-in-rohingya-refugee-camps-idUSKBN1CS2WF, accessed on July 2018.

Goodwin-Gill, GS., "The Politics of Refugees Protection", Refugee Survey Quarterly, No. 27, Issue 1, 2008.

Heise L, Ellsberg M, and Gottemoeller M, "Ending Violence against Women", Population Reports, Series L, No. 11, 1999.

Joachim, Jutta, "Framing Issues and Seizing Opportunities: The U.N, NGOs and Women's Rights", International Studies Quarterly, Vol. 47, Issue 2, 2003.

Kaur, Amarjit, "Refugees and Refugee Policy in Malaysia", UNEAC Asia Papers, No. 18, 2007.

Manjoo, Rashida and Calleigh McRaith, "Gender-Based Violence and Justice in Conflict and Post-Conflict Areas", Cornell International Law Journal, Vol. 44, No. 11, 2011.

Matthew, Penelope and Tristan Haley, "Refugee Protection and Regional Cooperation in Southeast Asia: A Fieldwork Report", http://www.mcrg.ac.in/WC 2015/ Reading/D RefugeeProtection.pdf, accessed on December 2017.

Mizzima News, "Burma: Amid Praise, End to Sexual Violence: G8", http://www. mizzima.com/news/world/9219-amid-praise-end-to-sexual-violence-g8, accessed on February 2018.

Moretti, Sebastien, "The Challenge of Durable Solutions for Refugees at the ThaiMyanmar Border", Refugee Survey Quarterly, Vol. 34, No. 3, 2015.

Morsink, Johannes, "Women's rights in the Universal Declaration", Human Rights Quarterly, Vol. 13, No. 2 , 1991.

Office of the Special Adviser to the Secretary-General on Gender Issues and Advancement of Women (OSAGI), "Landmark resolution on Women, Peace and Security", http://www.un.org/womenwatch/osagi/wps/, accessed on January 2018.

Phanit, Soukphaphone, "The Relationship Between The Lao People's Democratic Republic (Lao PDR) and the ASEAN Commission for the Promotion and Protection of the Rights of Women and Children (ACWC) with a focus on women," http:// unitec.researchbank.ac.nz/handle/10652/2318, accessed on February 2018.

Report Medecins sans Frontieres, "10 Years for the Rohingya Refugees In Bangladesh: Past, Present and Future", http://www.msf.org/en/article/ten-years-rohingyarefugees-past-present-and-future-report-summary, accessed on December 2017. 
Sangiam, Tanakorn, "DPM stressed local authorities practices for Rohingya refugees",http://thainews.prd.go.th/website en/news/news detail/ WNPOL5805180010012, accessed on June 2017.

Singh, B., "ASEAN, Myanmar and the Rohingya Issue", Himalayan and Central Asian Studies, Vol. 18, Issue 1, 2014.

UN Women, "Gender Briel on Rohingya Refugees Crisis", http://asiapacific.unwomen. org/en/digital-library/publications/2017/10/gender-brief-on-rohingya-refugeecrisis, accessed on January 2018.

UNHCR, “Figures at a Glance", http://www.unhcr.org.my/about us-@-figures at a glance.aspx, accessed on February 2018.

--------, "Handbook for the Protection of Women and Girls, Provisional Release for Consultation Purposes", http://www.unhcr.org/protection/women/47cfa9fe2/ unhcr-handbook-protection-women-girls-first-edition-complete-publication.

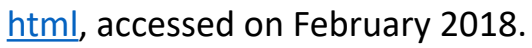

United Nations Children's Fund (UNICEF), "UNICEF and Jawwal reach more than half a million people in Gaza with life-saving and child protection messages", https:// www.unicef.org/oPt/media 9557.html, accessed on February 2018.

United Nations High Commissioner for Refugees (UNHCR) Executive Committee Conclusions on the Refugee Women and International Protection No. 39 (XXXVI) 1985.

United Nations Human Rights Office of the High Commissioner (OHCHR), "Women's Rights are Human Rights", http://www.ohchr.org/Documents/Publications/HRPUB-14-2.pdf, accessed on January 2018.

United Nations, "UN Refugee Agency Redeploys Staff to Address Humanitarian Needs in Myanmar", https://news.un.org/en/story/2012/06/414422-un-refugeeagency-redeploys-staff-address-humanitarian-needs-myanmar, accessed on January 2018.

Willman, Allys M. and Crystal Corman, "Sexual and Gender Based-Violence: What is the World Bank Doing and What We Have Learned", A Strategic Review, 2013.

Women, Peace and Security, "Study Submitted by the Secretary-General pursuant to Security Council Resolution 1325" http://www.un.org/womenwatch/daw/ public/eWPS.pdf, accessed on February 2018.

\section{Legal Documents}

Universal Declaration of Human Rights 1948.

International Covenant on Civil and Political Rights 1966.

International Covenant on Economic, Social, and Cultural Rights 1966.

Convention on the Elimination of all forms of Discrimination against Women 1981.

Protocol to Prevent, Suppress and Punish Trafficking in Persons, Especially Women and Children 2000.

Declaration of the Advancement of Women in the ASEAN Region 1988.

United Nations Entity for Gender Equality and the Empowerment of Women (UN 
Women) Beijing Declaration and Platform for Action 1995.

ASEAN Declaration on Elimination of Violation against Women in 2004.

ASEAN Charter 2008.

Hanoi Declaration on the Enhancement of the Welfare and Development of ASEAN

Women and Children 2010.

ASEAN Declaration of Human Rights 2012.

ASEAN Declaration on the Elimination of Violence against Women and Elimination of Violence Against Children 2013.

ASEAN Convention Against Trafficking in Persons, Especially Women and Children 2015.

ASEAN Plan of Action Against Trafficking in Persons, Especially Women and Children 2015.

ASEAN Regional Plan of Action on the Elimination of Violence Against Women 2015. Joint Statement on Promoting Women, Peace, and Security in ASEAN 2017. United Nations General Assembly Resolution A/RES/48/104. 